\title{
ASEAN AND INDONESIA'S POLICY AGAINST WASTE IMPORT IN INDONESIA
}

\author{
${ }^{1}$ Dhiva Aribah Setyaningrum, ${ }^{2}$ Diva Putri Kaloko, ${ }^{3}$ Febriana Christianti, ${ }^{4}$ Inggrid Janna \\ Bella Sihaloho, ${ }^{5}$ Surya Tri Putri Dalapang \\ ${ }^{12345}$ International Relations, President University, Cikarang, Indonesia \\ ${ }^{1}$ dhiva.setyaningrum@student.president.ac.id, ${ }^{2}$ diva.kaloko@student.president.ac.id, \\ ${ }_{3}^{3}$ febriana.christianti@ student.president.ac.id, ${ }^{4}$ inggrid.sihaloho@student.president.ac.id, \\ ${ }^{5}$ surya.dalapang@student.president.ac.id
}

\begin{abstract}
Environmentalism has in common with other theories when it comes to making a movement. This theory talks about the environment, and its relationship with humans, how human behavior can impact the environment around it. This journal will discuss waste import as the main topic. Many people still do not know about the waste import activities carried out by the Indonesian. Therefore, we present data that describes how the process of these activities occurs, in relation to theory, other problems arising from the incident, Indonesian government policies and their implementation, as well as the right solutions that can be taken to prevent or even solve the problem.
\end{abstract}

Keywords: Environmentalism, Waste import, Policy, Government, Implementation

DOI: 10.33541/sp.v21i3.2417

Sociae Polites : Majalah IImiah Sosial Politik

Faculty of Social and Political Science, Universitas Kristen Indonesia

ISSN 1410-3745 print/ ISSN 2620-4975 online

Volume 22, Number 2 (July-December 2021)

Pages 187-203 


\section{Introduction}

The environment has an important role in the world. Environment plays an important role in healthy living and the existence of life on planet earth. Earth is a home for different living species, and we all are dependent on the environment for food, air, water, and other needs. The initial discussion about the environment was born from the thought of Thomas Malthus (1766-1834), who stated that humans would eventually experience inevitable conflict, while the human population will increase in a geometric series (Jerald Mast, 2013: 729-730). Therefore, it is important for every individual to save and protect our environment. According to Dana M. Lovelady defines environmentalism can be described as a social movement or as an ideology focused on the welfare of the environment. Moreover, there is an environmental issue that has a big impact, which is called Waste Plastic, which is the most serious problem in every country, which will bring damage to the environment, and also it will be a disease to the country.

Unfortunately, our world still has this problem; humans are still limited to understand the impact of waste plastic. The problem that wants to discuss the waste plastic is there is not only a country that has a waste of plastic problems, but there is also a problem, which is a waste import from another country. It is taken seriously because no country wants to allow the import of waste; back to the case of waste import, one of the countries that have this impact in Indonesia. As one of the big countries that have the highest population, Indonesia has a major plastic waste problem on its hands. According to a study by the University of Georgia, an estimated 3.22 million metric tons of plastic waste is tossed annually into the ocean surrounding Indonesia, while another 8.82 million metric tons of China's plastic waste also makes its way into the ocean. It also culminates in the increase in shipments of this waste from Western countries after China banned imports last year. Based on Yarsley \& Couzens 1945, the durability of plastics and their potential for diverse applications, including widespread use as disposable items, were anticipated, but the problems associated with waste management and plastic debris were not. In fact, the predictions were 'how much brighter and cleaner a world than that which preceded this plastic age.' Toxins leach from plastic as it breaks down, posing health risks for animals while also entering the food chain and eventually ending up on our plates.

According to the statement above, this is important to consider that waste import is the issue that must be solved. Not only Indonesia, the Southeast Asian country already struggles to deal with its waste, which often goes into landfills or is dumped in rivers. Besides, there is also the problem of illegal waste dumping by exporting countries that intentionally mislabel garbage and by recycling firms that smuggle it into the region. Though the global trash trade is a boon for private companies, Southeast Asian governments are pushing back against it, with some imposing their own bans on waste imports. Because of the ban on waste plastic in China, Indonesia is the second-biggest contributor to waste plastic. This ban also would not only clean up the country but also force other countries to better manage their own trash. Because of that, Southeast Asia gets affected by the exporting countries that want to remove their waste by exporting to other countries. Between 2016 and 2018, regional imports of plastic waste surged 171 percent to over two million tons, much of which was infected and neglected. "The nation that the earth is not simply a resource to be used by humans. Humans should consider themselves as part of a complex, interdependent system rather than consumers of natural goods and should develop compassion for nonhumans. To fail to understand this point 
was to risk destroying the natural world through narrow-minded, selfish ambition" (Sam Atkinson, 2013: 292).

On the other hand, the cognition regarding these issues and the argument say that because of the high cost to recycle their waste plastic in their county. Indonesia is also the one who gets the big impact of this waste import. To solve this problem, the Government of Indonesia also hopes that Southeast Asia, which is also included in the ASEAN country to prevent this illegal waste plastic as regulated in the international agreement. Interestingly, some Southeast Asian countries have taken a serious issue, such as in recent months taking action to stem the flow of trash. Moreover, the impact of this waste plastic is still hard to manage and also can destroy environmentalism in the country that gets impacted. Besides, the waste import is not only the waste plastic that can be recycled but also hazardous and toxic waste, thus polluting the surrounding environmentalism. But the reality is, low regulations about the waste import and limited enforcement capacity allow local importers to exploit loopholes in existing laws to legally carry waste. In order to carry out the problem of plastic waste and to maintain an effective approach to sustainable urban development, policymakers, which are the Government, must collaborate with the private sector and the international community, e.g., ASEAN, to develop relevant legal frameworks and also to enforcement mechanisms.

The ASEAN, as the regional organizations, should solve this problem. An ASEAN-level response can ensure an extra layer of protection. For example, the ASEAN can use its influence as a trading bloc to ensure no trade-in waste transpires within the region. Because not only to focus the waste import happening in Indonesia, but other countries in ASEAN also get affected. Because of that, an ASEAN framework agreement on this issue could be negotiated to create a common regional approach to plastics, of which the region serves as a hotspot. A regional agreement would demonstrate the resolution and ability of ASEAN Member States to jointly address common challenges and could set a precedent for a future global agreement on plastics. From that stated above, this paper discussed the impact of waste plastic on Indonesia's Environmentalism. It is continued how the Indonesian Government resolves this problem with existing policies and ASEAN's response as a regional organization to resolve these problems.

\section{Literature Review}

The environmental problem persists and gets worse from year to year. The environment has limited resources, such as land, clean water, clean air, and other biodiversity. Globalization, especially in the field of technology, has brought a great impact on the balance of the environment. The drastic climate change has brought environmentalism into a new focus. The foundation of this movement began with the growth of the industry in England, which was followed by World War 1, which provided a genuine example of environmental destruction.

According to Meriam-Webster Dictionary, Environmentalism is defined as a theory that sees the environment rather than heredity as an important factor in the development and especially the intellectual and cultural development of the individual or group. Dana M. Lovelady defines the environment can be described as a social movement, or an ideology focused on the welfare of the environment. He further explained his ideas about the movement to seek to protect and conserve the elements of the earth's ecosystem, including water, air, land, animals, and plants, along with entire habitats such as rainforests, deserts, and oceans. The article from Dana also describes the 
concepts of dealing with environmental problems, including overpopulation, commercial logging, natural resource management, urbanization, and global warming. In his writing, he analyzes the historical roots of environmentalism. The Industrial Revolution initiated many changes, and westerners began to realize that their behavior towards the environment had a negative impact (Stradling and Thorsheim 1999). Developing industrial cities set up factories, causing pollution and deforestation. This is the beginning of an awareness that environmental protection is more concerned with preventing unwanted damage.

Environmentalism is a social and political movement that is focused on preservation, restoration, and improving the quality of life through public education, advocacy for community planning changes, changes in the financial economy, and overhauling state policies (WALHI, 208: 69). It is called a social movement because this movement focuses on issues related to social issues involving living things. And it is also called a political movement because this movement seeks to organize this movement through government support through environmental policies.

Environmentalism is focused on several issues of environmental damage such as climate change, ozone layer depletion, species extinction as plants and animals, environmental pollution, forest fires, population density, and many more. Besides Environmentalism, Green Politics is a branch of the fruit of thought. The environment is still associated with the balance of nature. Green politics is different from environmentalism. Ernest Haeckel (1873) stated that environmentalism discusses the preservation and protection of nature as a whole for the sustainability and usefulness of mankind, while green politics is concerned with the adoption of a geocentrism perspective (the understanding of the earth as the center of the universe).

In the journal Environmentalism and Green Politic: Theoretical Discussion, there are several differences between Environmental and Green Politic. The writer's view of the difference in understanding of the two theories. Great attention of Green Politics environmental issues related to involving politics in maintaining the balance of nature. Harmony of the man with nature through political role to regulate the natural good governance to still consider the environmental impact in carrying out a policy.

According to Patterson (2005), Green Politic provides an explanation of the ecological crisis currently facing humans. The focus on this crisis makes the environment became something important that needs to be maintained in balance and sustainability. This Green Politic is providing a normative basis for the problem of the ecological crisis. (Patterson, 2005: 257). In explaining Green Political Theory, Patterson provides a boundary between Green Political Theory and Environmentalism. Environmentalism deals with frameworks that exist in political, social, economic, and normative structures in the world of politics. Which, in essence, is trying to fix environmental problems that have occurred. Meanwhile, Green Politics Theory in International Relations considers that the previously formed structure is the main basis and core for environmental damage to occur (Patterson, 1996: 337).

With the increase in population and the increasing productivity of humans, it has resulted in new problems such as an increased population, less green land, and overconsumption of unused production products or so-called garbage. The Ministry of Environment and Forestry of Indonesia stated that the national waste pile amounted to 170,000 tons per day, meaning that every day one person produces at least $0.7 \mathrm{~kg}$ of waste per day environment in Indonesia. The same thing would apply to other countries, 
especially the industrialized countries, which produce in large quantities and produce waste.

Waste is essentially a material that is not used. Waste is a useless product of human activities that physically contains the same substance that is available in a useful product (White et al., 1995). Wastes have also been defined as any product or material which is useless to the producer (Basu, 2019). Waste is classified into three groups, namely organic waste, inorganic waste, and toxic waste. Not all waste can be decomposed or reused, or changed. We throw out over 2 billion tons of household waste a year globally. That's more than 60 tons of waste every second. Summed with factory waste, the numbers will increase as well. World Bank stated in What a Waste: An Updated Look into the Future of Solid Waste Management, "Poorly managed waste is contaminating the world's oceans, clogging drains and causing flooding, transmitting diseases, increasing respiratory problems from burning, harming animals that consume waste unknowingly, and affecting economic development, such as through tourism," said Sameh Wahba, World Bank Director for Urban and Territorial Development, Disaster Risk Management and Resilience.

The impact of the waste above has occurred over the decades. Posts from the World Bank show the number of garbage that has generated more than in 2016. The World Bank estimates that the waste generated will continue to increase along with economic development and population growth. Assessing sensible waste management and in accordance with the Government's economy, followed by the data and the calculation of good, solid waste management is expected to be able to run well. In addition, this article supports countries with waste producers to be able to properly manage their generated waste, both in terms of economy, social (urbanization), and the environment.

At The Export of Hazardous Waste Article, Paul E. Rosenfeld, Lydia G.H. Feng, in Risks of Hazardous Wastes, 2011 associates the social life of people in developing countries with the impact of the waste is not managed properly. It is addressing the problem of poverty, local governance, and the role of global trade, which are interrelated in this topic. This paper describes the importance of legal responsibility in overcoming the fate of the environment and communities that have been contaminated and polluted by waste. This legal responsibility should also address the fate of environments and communities in developing countries already consumed by contamination ( $\mathrm{Yu}$ et al., 2010).

Management and Export of Wastes: Human Health Implications by $\mathrm{V}$. Ustohalova, 2011 wrote about hazardous waste International. She was explaining the serious historical waste that causes extreme environmental pollution in the 1970s and 1980s. The impact of hazardous waste on the environment has a profound effect, particularly on water, air, and soil quality and ultimately on human health. In this way, the regulation of the management and disposal of hazardous waste takes place in cooperation at the global level. Indicates the beginning of the delivery of waste to developing countries and Eastern Europe. In that paper, there are factors that led to the preparation of the Basel Convention in 1989. Basel Convention is the first international instrument in the effort to control the management and handling of hazardous waste. This convention was held in Basel, Switzerland, on March 22, 1898. This multilateral convention regulates export and import activities, issues obligations, and manages waste commodities in an environmentally friendly manner with the aim of keeping developing countries from becoming targets of hazardous waste (Kumer, 1995). 


\section{Research Methods}

The method used is the qualitative method and quantitative methods. Which, the method itself has a connection with the method. These are the Primary Method and Secondary Method. Qualitative methods can be said to be secondary methods because it contains a method where the explanation is taken from books, journals, scientific works, and so on, as for quantitative methods related to the primary method, which the method uses a survey in the surrounding environment. Therefore, the purpose of the method will be explained above, as described by its understanding.

The purpose of the qualitative method is used as a reference for how much action or steps have been carried out by the Government in dealing with the problem of importing the waste; used to know what the impact of the waste imports; As well as what types of import waste that can have a negative impact on the recipient. The purpose of the quantitative method is to find out how a year the community regarding the import problem; and the response and suggestions from the community themselves to the problems discussed.

\section{Results and Discussion}

The author conducted online surveys to general public in Indonesia. From a total of 43 responses, $58.1 \%$ stated that they did not know about the problem of importing waste in Indonesia. Thus, the number of responders who knew about the problem was 41.9\%. Suppose totaled using the number of individuals. So, the number of people who know about the problem is 18 people, and 25 other people do not know about it.

It indicates a sense of lack of understanding of the problems in his own country. It can be said indeed, the level of awareness of the Indonesian people is still low to discuss the problems in his country even though most of the problems can have a negative impact on them later on. The making of surveys that we have done by using a questionnaire found some of the responses that were indifferent. Because they consider it, it is not a matter of important things that must be deposited with other problems such as corruption, and so on, which are closely related to the issue of the Indonesian economy.

However, on the other hand, there are still many who are aware and give opinions that are in accordance with the reviews provided. Like the opinion stating that it is good if the garbage imports are stopped in Indonesia, due to the amount of household waste Indonesia itself is high. Not to mention the waste produced from factories or excavation materials in Indonesia. The amount is no longer said to be, but it's already excessive. So, if the garbage imports are still implemented, it means that some people who agree to be garbage imports to Indonesia hope Indonesia will become the largest waste producing country later on. There are also suggestions from the respondent. He still agreed to import garbage to Indonesia. However, the Government must be ready to prepare a special place for good waste management. Far from the crowd, there are also special machines that can work instantly. And the workers in that section also have good people who know correctly about the types of garbage. So that it can sort out waste according to its type, in fact, it can be done with advanced machines. So, the workers are enough just by paying attention to machines that work without having to sort themselves.

Suppose all the suggested things can be applied or maybe one of them. Indonesia will soon be clean of this problem or can even be clean of dirty environmental problems due to garbage or waste. It is also good for the Government to provide the greatest 
education for problems in Indonesia in such away. So that they do not look at the problem being faced by their country, they can also take part in critical thinking and even giving the right solution, which is in accordance with the expectation of the problem.

Every country strives to sterilize its territory from the garbage. Since 2018, waste exporting countries have targeted new countries as destinations for waste delivery, namely countries in ASEAN. As explained earlier, this is related to the Chinese government's new policy of drastically reducing waste imports from the European Union and America. Therefore, the waste import is a serious problem in the ASEAN region, especially in Indonesia.

In 2018, data from the Central Statistics Agency (Badan Pusat Statistik) showed an increase in Indonesia plastic waste imports by $141 \%$ (283,152 tons). This figure is the highest peak for plastic waste imports over the last ten years, wherein 2013, Indonesia's plastic waste imports were around 124.433 tons. The increase in plastic waste imports was not matched by export. In 2018 the export figures decreased by $48 \%$ (98.450 tons). This figure indicates that there are 184.702 tons of waste still in Indonesia, apart from the burden of managing our domestic waste in our own country. Export and import transactions in Indonesia do operate from business to business. However, in the field, several companies have found the practice to re-sell or give their waste to traders who are outside their industrial system.

In mid-June 2019, the Indonesian people were quite shocked by the news of plastic waste imports. Indonesia is estimated to receive at least 300 containers, most of which go to East Java every day. Based on Jambeck's data (2015), Indonesia is in the second place in the world to produce plastic waste to the sea, reaching 187.2 million tons, after China got 269.9 million tons (CNN Indonesia 2016). However, with this large amount, Indonesia still imports waste from other countries. Then why does Indonesia still import waste if Indonesia is already the second-largest waste producer?

This is related to the need for industrial raw materials. The paper industry is an example of this industry, where the paper industry requires waste paper to be processed into new paper. Also, it turns out that the plastic raw material industry still largely depends on imports. According to the Director-General of Chemical, Pharmaceutical, and Textile Industries of the Ministry of Industry, Muhammad Khayam, one industry requires around 8 million tons of raw materials. However, only 2.5 million tons can be fulfilled by the local (Kumparan 2020).

Indonesia can fulfill the industry's needs if the government is serious about handling waste cases regarding the proper sorting and processing of existing waste. According to research by Sustainable Waste Indonesia in 2017, Indonesia produces 6.5 million tons of waste paper per day, with 14\% (910 thousand tons) of which is plastic and $9 \%$ paper, but the waste is not well managed. $69 \%$ entered landfills without being properly managed, $24 \%$ were not managed at all, and only $7 \%$ of the waste was recycled. If the government can control the waste properly, the intensity of waste imports can be reduced so that the waste will not accumulate in this country. Besides, the waste import activity is because the price of imported waste is lower than the waste collected by scavengers. Therefore entrepreneurs and industrialists tend to buy imported waste. This is also supported by business motives to get the maximum profit.

Usually, the waste is sent from developed industrial countries such as America, Japan, Germany, the Netherlands, etc. The developed countries generally know how to sort the waste by type but do not know how their waste will end. Therefore, they seem to pass their responsibility to other countries, usually developing countries. In several cases, 
it was also stated that importing waste from developed countries was paid, where those who received it would get a certain amount of money, but this was still being investigated to obtain proof of its validity.

The case of waste import becomes a serious concern when the number of imports increases drastically. Some hazardous material or called B3 (Bahan Berbahaya dan Beracun) is found in the imported waste. The policy regarding imported waste is also regulated in the Indonesian Law, where through this policy, the activities of importing waste can be controlled under government authority.

\subsection{Waste Import Policy in Indonesia and Its Implementation}

As previously explained that in addition to being a social movement, environmentalism is also a political movement directed at overhauling state policy. Through various government policies, the movement seeks to resolve environmental issues. Besides, according to understanding environmentalism awareness, creating awareness of the environmentalism movement requires strong cooperation between the government and the community. According to Lester Milbrath (1986), environmentalism has eight principles in which these principles, if applied, can help individuals and groups become wiser in utilizing natural resources, can also be a consideration for the government in issuing policies that will affect environmental conditions. The eight principles of environmentalism according to Milbrath are the following: 1) highly value for nature; 2) have sympathy for others; 3 ) greater emphasis on job satisfaction; 4) growth limitations; 5) the new social paradigm; 6) greater appreciation of participation roles, simple living, and cooperation; 7) more appreciative of public solutions on a range of issues than private solutions; 8) precise planning to avoid the emergence of sensitive technologies toward the environment (John Situmeang, tth).

Relating to government policy itself to overcome the environmental issue, in this case about the waste import that was taken as our case study in this journal paper, Indonesia, which is one of the countries that receives waste import, actually has a policy or Law governing waste import which is contained in Law No. 18/2008, Law No. 32/2009, and Permendagri No. 31/2016 which was later revised to Permendagri No. 84/2019. These existing rules consist of two types, namely those that permit certain restrictions or preconditions and which prohibit without limitation. The cooperation makes these three ministries, namely the Ministry of Industry, the Ministry of Environment and Forestry, and the Ministry of Commerce. Here is an explanation of the Law and Permendagri. Law No.18/2008 about Waste Management, in Article 29 paragraph 1 explains the points that mention everyone is prohibited:

a. Putting garbage into the territory of the Unitary State of the Republic of Indonesia.

b. Importing garbage.

c. Mixing waste with hazardous and toxic waste.

d. Manage waste that causes pollution and/or environmental destruction.

e. Disposing of garbage is not in a designated place and is provided.

f. Perform waste handling with open disposal at the final processing site.

g. And/or burning garbage that does not comply with the technical requirements of garbage management.

While Law No. 32/2009 on Environmental Protection and Management regulates the prohibition on the insertion of B3 waste originating from outside the territory of the 
NKRI into the country's territory or to the environmental media of the NKRI. Furthermore, Permendagri No. 31/2016 on Non-Hazardous and Toxic Waste Import Provisions has been revised in 2019 to Permendagri No. 84/2019 on Non-Hazardous and Toxic Waste Import Provisions as Industrial Raw Materials. This revision was carried out to tighten the rules against importers. The government wants to prevent the influx of waste, especially plastic, that cannot be processed and is not needed by the Indonesian industry. Besides, this revision was also carried out to revamp surveillance so that the opportunity of smuggling plastic waste in Non-B3 waste could be prevented. The following is a comparison table between these two Permendagri.

Table 1.1 Comparison of Permendagri No. 31/2016 and Permendagri No. 84/2019

\begin{tabular}{|l|l|}
\hline \multicolumn{1}{|c|}{ Permendagri No. 31/ 2016 } & \multicolumn{1}{|c|}{ Permendagri No. 84/2019 } \\
\hline $\begin{array}{l}\text { For imports of paper and metal, exporting } \\
\text { companies do not need to use } \\
\text { recommendations. }\end{array}$ & $\begin{array}{l}\text { All new commodities should use } \\
\text { recommendations from the Ministry of } \\
\text { Environment and the Ministry of Industry } \\
\text { (including paper and metals). }\end{array}$ \\
\hline $\begin{array}{l}\text { Provisions regarding exporters who can } \\
\text { export Non-B3 waste are not regulated. }\end{array}$ & $\begin{array}{l}\text { Exporters exporting Non-B3 waste as } \\
\text { industrial raw materials must be registered } \\
\text { (Article 3 paragraph 3). }\end{array}$ \\
\hline $\begin{array}{l}\text { Import conditions apply only to Free } \\
\text { Areas and Free Ports (Article 27). }\end{array}$ & $\begin{array}{l}\text { Import conditions apply in Bonded } \\
\text { Storage, Free Trade Area and Free Port, } \\
\text { and Special Economic Area (Article 29). }\end{array}$ \\
\hline $\begin{array}{l}\text { Issuance of import approvals using wet } \\
\text { signatures. }\end{array}$ & $\begin{array}{l}\text { Issuance of import approvals using } \\
\text { electronic signatures. }\end{array}$ \\
\hline $\begin{array}{l}\text { It does not set the conditions for assigning } \\
\text { the destination port. }\end{array}$ & $\begin{array}{l}\text { The setting of the destination port, i.e. } \\
\text { Tanjung Priok Port, Tanjung Emas, } \\
\text { Tanjung Perak, Soekarno Hatta } \\
\text { (Makasssar), Belawan, Batu Ampar, } \\
\text { Teluk Among, and Merak (Article 3 } \\
\text { paragraph 4). }\end{array}$ \\
\hline $\begin{array}{l}\text { The mechanism of transporting non-B3 } \\
\text { waste imports to the destination port is not } \\
\text { regulated. }\end{array}$ & $\begin{array}{l}\text { Non-B3 Waste import transport } \\
\text { mechanism uses a direct shipment } \\
\text { method to get to the designated port. }\end{array}$ \\
\hline $\begin{array}{l}\text { Do not regulate provisions regarding the } \\
\text { management of Non-B3 Waste that cannot } \\
\text { be utilized in the production process. }\end{array}$ & $\begin{array}{l}\text { Non-B3 waste that cannot be utilized must } \\
\text { be processed in the production process, on } \\
\text { its own, in groups, or in cooperation with } \\
\text { licensed waste management companies. }\end{array}$ \\
\hline
\end{tabular}

From the table, it can be seen that the Permendagri No. 84/2019 can reduce the B3 waste smuggling gap in non-B3 waste imports because this waste import activity must get recommendations in advance from KLH (Ministry of Environment and Forestry) and The Ministry of Industry. The government can also monitor directly and control the waste import activities to the port of destination through the direct shipment mechanism.

Regarding the implementation of these policies or laws, we see that the policy's content with reality in the field is not following what is expected. For example, there is still B3 waste from abroad that passes to the territory of Indonesia. So far, the government's action is to re-export imported waste mixed with toxic and hazardous 
materials (B3) to the country of origin. By 2019, the Directorate General of Customs and Excise has returned as many as 374 containers of waste to their home countries where those containers come from several countries, such as us, France, Germany, Netherlands, UK, Australia, Hongkong, and Japan. Meanwhile, based on DJBC data, customs have banned about 2,194 containers where this ban is carried out in Tanjung Perak Port, Batam, Tanjung Emas, Tanjung Priok, and Tangerang. In-Law No. 18/2008 Article 39 has set the Law of imprisonment and fines for everyone who commits violations related to the applicable waste import policy. However, so far, the government has never imposed criminal sanctions on unlawful garbage importers. In comparison, the practice of importing illegal garbage continues to occur.

Besides, according to ICEL (Indonesian Center for Environmental Law), implementing regulations mandated by Law No. 18/2008 is still delinquent, for example in this Law ordered seven material content to be regulated in Government Regulation or Peraturan Pemerintah (PP) and two material content to be regulated in $P P$ and Regional Regulation or Peraturan Daerah (Perda) based on authority. It is recorded that until 2019, some material content mandated in PP level has been regulated in PP No. 81/2012 on Management of Household Waste and Similar Household Waste. However, several regulations delegated in other $P P$, including norms, standards, procedures, and criteria for implementing provisions of a general nature, are still not published. It is known that some delegate settings in PP are also set in Permen.

Referring to Law No.18/2008, the government was given one year to complete the $P P$, and Permen mentioned above. The local government was given three years to complete the orders at the Regional Government level. The sooner these arrears are resolved, the implementation of the regulations can be realized immediately. So far, we see that the implementation of Law No. 18/2008 itself has not been implemented optimally. This ultimately affects the problem of waste imports, as well as the management, handling, and disposal of waste where waste is often processed or disposed of in the wrong way and not following applicable regulations, as well as the absence of accountability in processing waste itself by individuals such as industrial companies in Indonesia and individuals or communities themselves.

Similarly, Law No. 32/2009 and Permendagri No. 84/2019, with the provisions included in both regulations, the things prohibited in these two regulations are still happening. Problems related to waste imports still exist and are trying to be handled as best as possible by the government to date. Waste - waste that should not be contained in the waste import, such as B3 waste, is still found and mixed with waste Non - B3 as factual evidence, namely data on cases of waste imports that we have described or mentioned in the previous discussion.

\subsection{Impact of Waste Imports on the Environment}

In the book "Steady-State Economics" by Herman Daly, an ecological economist in 1970, conventional economists often ignore the vital role of the environment in economic activities and studies where the background is the resource of all material and energy needs. The environment is a waste dumping industry that is part of a country's economic activities. According to the Greens, the obsession with economic growth that brings drainage and damage to the natural environment has also damaged vulnerable ecosystems where they are backing all life. It threatens the sustainability of the human species itself (Andrew Heywood, 2013: 243). 
As is the case with this waste import problem. B3 waste that often escapes government supervision at the heart of this waste import problem has damaged Indonesia's environment. The adverse effects are as follows.

- Disposal without B3 waste treatment containing heavy metals such as $\mathrm{Al}, \mathrm{Cr}$, $\mathrm{Cd}, \mathrm{Cu}, \mathrm{Fe}, \mathrm{Pb}, \mathrm{Mn}, \mathrm{Hg}$, and $\mathrm{Zn}$ as well as other chemicals used in the industry resulted in: decreased land or soil quality, polluted groundwater, the death of organisms living underground, and cultivation of crops became difficult because plants would be difficult to grow on contaminated land. Over the long term, humans and animals that depend on increasing plants will lack food sources.

- Disposal of such waste in aquatic ecosystems can damage those ecosystems and kill the living creatures in them. Another impact is the transfer of toxic substances from one living being to another: the body of a fish containing harmful toxins from its polluted habitat, if consumed by humans then toxins the poison is moved or entered into the human body.

- Processing and incorrectly handling these hazardous materials, such as using open combustion, increase the amount of carbon monoxide $(\mathrm{CO})$ and carbon dioxide $(\mathrm{CO} 2)$, resulting in air pollution and thinning of the ozone layer.

This pollution of soil, water, and air will ultimately harm all living beings who depend on these three aspects and, at the same time, impact other areas of human life, which is the economic field. Because after all, the economy is an inseparable part of environmental problems. The development and industry progress of the country is considered very important in today's global economy. And in the end, people sacrifice the environment to achieve economic growth. Unwittingly, humans have sacrificed his own life by destroying the nature in which humans and other creatures depend on it. As in his essay "The Tragedy of the Commons," which uses the metaphor "pastoral setting," Garret Hardin (1968) shows that a selfish individual or group will seek to maximize its selfinterest by exploiting everything to the point where ecology will be destroyed (Jerald Mast, 2013: 727).

According to Greens values that call for holistic thinking that recognizes the full implications of our place in the global ecosystem, whatever we do in one part of the system will affect all the other parts that ultimately resonate with humans themselves, as is the case in this imported waste problem, human waste is dumped into the environment and eventually pollutes the environment. Because of the polluted environment, living things that live in it will certainly be harmed, including humans themselves, where humans initiate all the problems that occur to the environment.

Therefore, to solve environmental problems, there needs to be a gradual change in viewpoint and human behavior. Naess (1929-2009) stated, man needs to realize that the Earth is not only a resource that man can use, but man is the complex unity of the Earth itself and let no man have a self - ambition to use natural resources that causes Earth's destruction.

Besides, in the implementation of environmentalism itself, two formulations have emphasized, that is sustainability which means giving consequences that human should not use the resource more than regenerative numbers, and accountability of resource which means each individual must acknowledge their self as a part of wide network society and has a responsibility to the entire network (John Situmeang, tth). These two formulations become a basis in utilizing natural resources that emphasize environmental preservation and minimize the impact of environmental detriment. Based on that concept, humans have to realize that natural resources cannot be used greedily to satisfying their 
interests, in this case, to achieve economic growth. Humans must be able to maintain and protect the environment and counterweigh human needs to preserve future generations.

In the literature review, it has been explained that Ernest Haeckel (1873) distinguishes between environmentalism and green politics. Based on this view, environmentalism views the interest of the environment as fully human interests, while green politics view humans as part of nature. Therefore humans must protect their environment. Environmentalism and green politics both have goals to create better natural and human life. Therefore, environmentalism and green politics have had a good impact on the development of improvements to various environmental problems.

Based on this explanation, it can be seen that environmental and green theories both discuss the environment and movement how humans as part of the natural environment take a role and have a response to the environment around them. Not only political movements capable of solving environmental problems, but there are also social movements. This movement focuses on human involvement in social issues, how they respond to these problems, and what is being done to prevent or reduce waste imports. The environmentalists themselves are a person or group of people who support the environmental movement, consisting of activists, volunteers, academics who have high values and strong views on environmental issues.

Several activists have voiced concerns about the waste import case, such as Wahana Lingkungan Hidup Indonesia (WALHI) in June 2019, who urged President Joko Widodo to stop waste import activities immediately. WALHI also highlighted the laws and regulations governing waste management, which are considered quite complicated. These organizations also believe that if there is pollution or environmental damage, the authorities must investigate it thoroughly without waiting for public complaints. Besides, the movement carried out by WALHI also aims for the government to immediately tighten the regulations regarding waste management, including imported waste, improve waste management so that it can be recycled economically. The local and central governments must also issue regulations to stop producing single-use plastic packaging, which aims to reduce the production of plastic waste. In November 2019, international waste trade regulatory organization, Basel Action Network (BAN) together with the Indonesian environmental organizations such as Ecoton, WALHI, and Nexus3 stated that the situation of waste imports in Indonesia is in dire and uncontrollable conditions and could only be resolved by the government of Indonesia if the government is more responsible in handling illegal waste shipments arriving in Indonesia while imposing a full ban on the future imports.

Then, environmentalist also calls on Indonesia to ensure that illegally imported waste that has been sent to Indonesia is sent back to its country of origin by the rules of the Basel Convention, make restrictions on waste imports like China so that Indonesia is not considered a destination for new waste disposal, the waste shipment deemed illegal can be brought to court as fraud, the government must request the original shipping letter as well as the shipping container number (Bill of Landings). This document can be obtained from the shipping lanes involved as well as from companies conducting reexports. Both notification documents and re-exports bills need to be made public to ensure full transparency. Finally, an independent monitoring committee should be set up to import or export waste and re-export comply with all government regulations and orders.

\subsection{ASEAN's Policy about Waste Import}


Since the increasing number of waste imports in the ASEAN region, this problem has become severe for environmental activists and governments in ASEAN countries. Since the discovery of the fact that some imported waste is often a mixture of plastic that cannot be recycled and contaminated and cannot be processed. As a country in Southeast Asia that does not yet have good recycling facilities and mechanisms, this is detrimental to ASEAN countries. The illegal waste import activities also cause harm to the receiving countries of waste because they cannot take responsibility for the waste, which causes environmental pollution for the country.

Since the surge in imports of waste, ASEAN countries have taken steps to face this wave, as Thailand has announced its intention to ban plastic waste imports in 2021. Malaysia returns the waste to the origin of the country of delivery and issues a new permit for plastic waste. The Philippines also returns waste to its country of origin, Vietnam has also stopped issuing licenses for waste imports and has sent illegal shipments. Indonesia is also following its neighbors' steps, returning waste known to contain hazardous and toxic materials.

The concern is when it turns out that ASEAN does not have firm and clear regulations regarding this environmental issue. This can be seen at the ASEAN Summit in June 2019, where the conference has the theme "Partnership for Sustainability," which focuses on economic, trade, and security issues, but the main points regarding the sustainability and growth of the ASEAN region itself are not discussed.

Therefore, the ASEAN community, especially environmental activists, urged ASEAN leaders to discuss the imported waste case. One environmental group that has a concern about this issue is Greenpeace Southeast Asia. Greenpeace Southeast Asia demands that ASEAN leaders discuss this issue at the summit meeting and make a joint declaration to overcome the ASEAN region's waste crisis. Greenpeace has also called for a ban on single-use plastics. The movement carried out by Greenpeace is an implementation of the environmental theory, in which there is a movement towards handling environmental problems.

\section{Conclusions and Recommendations}

The environmental issue regarding waste imports is a very concerning matter, especially since Indonesia's high number of waste imports. However, it turns out that there are still many Indonesians who do not know about this case. Waste import activities are undoubtedly detrimental to ASEAN countries, including Indonesia, because waste can have a negative impact on the environment for the countries receiving the waste and indirectly affect other aspects of life such as the economy, tourism, and health. It is not without reason that the Indonesian government accepts waste imports. This is supported by industrial interests where the state cannot meet the need for industrial raw materials. However, this becomes a problem when imported waste is found in hazardous and toxic materials and is carried out illegally. Indonesia has a policy regarding waste imports, but in its implementation, the policies are still not well implemented, such as a lack of supervision and firm action from the government itself.

In view of what has been clarified in the past segment, to be a specific conversation. Thus, as a decision about this paper itself gives somewhat outline of the issues examined. Environmentalism is a social movement driven by environmentalists. This movement strives in all its ways, without violence, from street actions to political lobbying to public education - to protect natural resources and 
ecosystems. Environmentalists are concerned with water and air pollution issues, species extinction, energy-hungry lifestyles, the threat of climate change, and genetic engineering in food products.

This difficulty itself has gotten resistance from Indonesia's Public authority, which they have written in Law Number 18 of 2008, Law Number 32 of 2009, and Permendagri Number 31 of 2016, which were later modified to Permendagri Number 84 of 2019. Next, we will be explained the opinions of several participants who expressed their views through the google form that we have created. The opinions expressed are not only hopes but also suggestions for solutions that, in their view, are appropriate so that the problem can be resolved wisely.

Concerning this problem, we recommend that the Indonesian government take a firm stand against violators of waste imports and implement regulations following existing provisions, for example, by tightening supervision \& sorting when imported waste containers enter Indonesian territory, paying attention and limiting the permits of each allowed company to import waste into Indonesia by the prevailing laws and regulations of the Minister of Home Affairs. Also, we advise the government to pay attention to sorting waste, process it that is good and safe for the environment, and provide adequate facilities for use in the waste recycling process. Suppose the government is able to do this. In that case, we believe the level of waste imports can be appropriately controlled because the waste has been processed and allows it to be used as industrial raw materials. Through good coordination between related governments, ministries, and customs, the implementation of the applicable policies can be optimal so that money regulation is not limited to "black and white."

The campaign that was initiated by Greenpeace, namely "Prohibition of Use of single-use plastics," can also be run by everyone, because they have a concern about the issue of waste that can prevent environmental pollution from waste, especially plastic waste, which is difficult to recycle. For ASEAN itself as a regional organization, there is still no clear policy regarding importing waste into the ASEAN region. Therefore, the activities of importing waste from developed countries have continued until now. Since ASEAN does not yet have a clear policy on this issue, so far, each ASEAN member government has made its policies, with the hope that ASEAN as a regional institution in Southeast Asia will be able to respond to this issue quickly.

Trash is something that cannot be separated from human activities; therefore, both the government and the community must be able to work together to handle waste cases. If the government must be serious in dealing with imported waste, the community must also be serious in dealing with domestic waste. If these two things can be carried out properly, we are sure that excessive waste accumulation will not occur. 


\section{Bibliography}

\section{Books}

Eckersley, Robyn. (1992). "Environmentalism and Political Theory”. UCL Press.

Tim Dunne, Milja Kurki, Steve Smith. (2013). International Relations Theory. Oxford University Press.

\section{Article}

Jain, Aarushi. (2020). Trash Trade Wars: Souheast Asia's Problem With the World's Waste. May 8. Accessed October 19, 2020. https://www.cfr.org/in-brief/trashtrade-wars-southeast-asias-problem-worlds-waste.

Lovelady, Dana M. (2019). "Environmentalism," Learning to Give, https://www.learningtogive.org/resources/environmentalism

Science Direct Topics. (n.d). Waste Eport. Accessed November 19, 2020. https://www.sciencedirect.com/topics/earth-and-planetary-sciences/wasteexport.

The ASEAN Post Team. (2018). Indonesia's Plastic Waste Problem. July 6. Accessed October 19, 2020. https://Theaseanpost.Com/Article/Indonesias-Plastic-WasteProblem.

Wright, Thomas. (2017). How can Indonesia win against plastic pollution? September 3. Accessed October 19, 2020. https://theconversation.com/how-can-indonesia-winagainst-plastic-pollution-80966.

Wen Xu, Wei-Qiang Chen, Daqian Jiang, Chao Zhang, Zijie Ma, Yan Ren \& Lei Shi (2020) Evolution of the global polyethylene waste trade system, Ecosystem Health and Sustainability, 6:1, DOI: 10.1080/20964129.2020.1756925

$\mathrm{Xu}$, Kenneth Wee and Kathy. (2020). Southeast Asia's plastic waste problem. February 27. Accessed October 20, 2020. https://kontinentalist.com/stories/southeast-asiaforeign-garbage-plastics-waste-pollution.

\section{Journals}

Amasumo, Ebikapade, and Jim Baird. (2016). "The Concept of Waste and Waste Management. Journal of Management and Sustainability."

Lestari, Yeni. (2018). Discussion Journal. "Environmentalism dan Green Politics: Pembahasan". Theoretical.

Novaradila, G., \& Prigi A. (2020). Dampak Sampah Impor terhadap Lingkungan dan Kesehatan. Ecoton. n.d. Accessed October 19, 2020. http://ecoton.or.id/wpcontent/uploads/2020/03/Dampak-Sampah-Impor-Terhadap-Lingkungan-danKesehatan.pdf.

Haryadi, Yulius, Reni Windiani, \& Mohamad Rosyidin. (2017). "Pelanggaran Inggris terhadap Konvensi Basel: Digital Dumping Ground di Nigeria." Journal of International Relations 3, no. 4: 32-39. October 8, 2020. https://ejournal3.undip.ac.id/index.php/jihi/article/view/17577 
Wahyudin, Bayu. (2020). "Ancaman Kenaikan Muka Air Laut Bagi Negara-Negara di Kepulauan Pasifik." alauddin.ac.id/index.php/rir/article/view/15421

http://journal.uin-

\section{Internet}

Aninda, Ina. (2019). Ringkasan Kebijakan: Perjuangan Asia Tenggara Melawan Perdagangan Limbah Plastik. July 10. Accessed October 20, 2020. https://www.greenpeace.org/indonesia/publikasi/3267/ringkasan-kebijakanperjuangan-asia-tenggara-melawan-perdagangan-limbah-plastik/.

Asia Sentinel. (2019). Southeast Asia Discovers it Can't Say No to All Waste Imports. Accessed November 1, 2020. https://www.asiasentinel.com/p/southeast-asiawaste-imports .

Bank, World. (n.d). "What a Waste: An Updated Look into the Future of Solid Waste Management,". Accessed October 31, 2020. https://www.worldbank.org/en/news/immersive-story/2018/09/20/what-a-wastean-updated-look-into-the-future-of-solid-waste-management.

Buakamsri, Lea Guerrero \& Tara. (2019). Mengapa Masalah Impor Sampah Harus Masuk ke dalam Agenda Pertemuan ASEAN. June 21. Accessed October 20, 2020. https://www.greenpeace.org/indonesia/cerita/3099/mengapa-masalah-imporsampah-harus-masuk-ke-dalam-agenda-pertemuan-asean/.

CNBC Indonesia. (2019). Kenapa Indonesia Impor Sampah? July 6. Accessed October 19, 2020. https://www.cnbcindonesia.com/news/20190706182210-483157/kenapa-indonesia-impor-sampah.

CNN Indonesia. (2019). 882 Kontainer Sampah Plastik Diimpor ke Indonesia sejak April. $\begin{array}{lllll}\text { September } & 18 . & \text { Accessed } & \text { October } & 19,\end{array}$ https://www.cnnindonesia.com/nasional/20190918201548-20-431725/882kontainer-sampah-plastik-diimpor-ke-indonesia-sejak-april.

-. (2016). Indonesia Penyumbang Sampah Plastik Terbesar Ke-dua Dunia. February 23. Accessed October 19, 2020. https://www.cnnindonesia.com/gayahidup/20160222182308-277-112685/indonesia-penyumbang-sampah-plastikterbesar-ke-dua-dunia.

- (2019). Pemerintah Ancam Pidana Importir Sampah. November 6. Accessed October 19, 2020. https://www.cnnindonesia.com/ekonomi/20191025125438-532442823/pemerintah-ancam-pidana-importir-sampah.

Greenpeace. (n.d). Tidak Ada Tempat Untuk Sampah. Accessed October 20, 2020. https://www.greenpeace.org/indonesia/aksi/tidak-ada-tempat-untuk-sampah/.

IDN TIMES. (2019). Kenapa Negara Maju Kirim Puluhan Kontainer Berisi Sampah ke Indonesia? June 19. Accessed October 19, 2020. https://www.idntimes.com/science/discovery/nena-zakiah-1/alasan-negara-majumengirimkan-kontainer-berisi-sampah-ke-indonesia/6.

KOMPAS.com. (2019). Di Balik Impor Sampah Plastik Berkedok Bahan Baku Industri. $\begin{array}{llll}\text { September } 20 . & \text { Accessed } & \text { October }\end{array}$ https://www.kompas.com/tren/read/2019/09/20/125000465/di-balik-imporsampah-plastik-berkedok-bahan-baku-industri?page=all.

- (2019). Jadi Keresahan, Bagaimana Sebeneranya Aturan Impor Sampah di Indonesia? November 21. Accessed October 19, 2020. 
https://www.kompas.com/tren/read/2019/11/21/083400265/jadi-keresahanbagaimana-sebenarnya-aturan-impor-sampah-di-indonesia-?page=all. .

Kumparan. (2020). Indonesia Impor 12 Juta Ton Sampah di 2019. July 9. Accessed October 19, 2020. https://kumparan.com/kumparanbisnis/indonesia-impor-12juta-ton-sampah-di-2019-1tlr4t5mJKH/full.

Marks, Danny. (2019). Southeast Asia's plastic waste problem. June 26. Accessed October 20, 2020. https://www.eastasiaforum.org/2019/06/26/southeast-asiasplastic-waste-problem/.

Mulyanigtias, D. (2018). Tinjauan Umum Tentang Pencemaran Lingkungan Hidup Akibat Pembuangan Limbah B3. Accessed October 19, 2020. http://repository.unpas.ac.id/34226/6/bab\%202.pdf.

Webster, Merriam. "Definition of Environmentalism." Dictionary by Merriam-Webster: America's Most-trusted Online Dictionary. Accessed October 24, 2020. https://www.merriam-webster.com/dictionary/environmentalism. 